\title{
A Cultural Hybridization Perspective: Emerging Academic Subculture among International Students from East Asia in U.S.
}

\author{
Jian Li \\ School of Education, Indiana University Bloomington, USA
}

Copyright $(2016$ by authors, all rights reserved. Authors agree that this article remains permanently open access under the terms of the Creative Commons Attribution License 4.0 International License

\begin{abstract}
This research examines the emerging academic subculture of international students from East Asia in U.S. academics from the cultural hybridization perspective. In a knowledge-based economy, international education plays a pivotal role in the global educational environment. Advocacy of international student mobility is essential; international student mobility fundamentally increases academic culture flows and the transmission and incorporation of different global cultural identity, while simultaneously leading to the breakdown of individual cultural identity in a new cultural context. In addition, the international students can be a catalyst and may generate new academic subcultures in new academic environments. This process contributes to the cultural hybridization process worldwide. The purpose of this article is to provide a qualitative research study on specific features of the international students' academic subculture. The research study findings display that East Asian international students cope in a vastly different academic culture by forming their own peer academic subculture and limiting interactions with faculty members and domestic students. The study recommends further research in this area and also promoting an effective relationship between faculty and international students as well as international students with domestic students.
\end{abstract}

Keywords International Students, Academic Subculture, Cultural Hybridization Perspective

\section{Introduction}

International student mobility is considered as one of the most significant phenomenon in the early twenty-first century global higher education system. Faced with the rapid development of the global economy, many higher education institutions are required to promote global educational achievements and performance. International student mobility has been regarded as a crucial index for the degree of globalization in the higher education systems in order to enhance the global educational competitiveness. Specifically, according to the data of the UNESCO Institute of Statistics (UIS), the total number of global mobile students rapidly increased from 2.2 million students in 2003 to 3.5 million in 2010. International student flows were summarized to from East to West and South to North both from vertical and horizontal perspectives (Kehm, 2005). More specifically, over three million postsecondary students enrolled in international education overseas (OECD, 2009). The most popular Western destinations included the U.S., UK, Austria, Canada, and New Zealand for international students seeking their tertiary education degrees. (OECD, 2009; UNESCO, 2008) Due to this rapid increase in student numbers and massive movement from East to West and South to West, international student flows have become a significant phenomenon in the sphere of global higher education system (Kehm, 2005). Moreover, based on the Institute of International Education 2014 data, most of the students studying in the United States from 2013-2014 came from East Asian countries, including China, South Korea, and Japan (See. Table 1). In addition, international student flows create academic subcultures among international students from an East Asian educational background. Subculture is defined as an alternate culture located within a primary, dominant culture and academic refers to an educational space. (Merriam-Webster, 2015) The number of East Asian international students in United States higher education institutions and international student flows in general are increasing. (See. Table 1) 
Table 1. Top 10 Places of Origin for the United States (2013-2014)

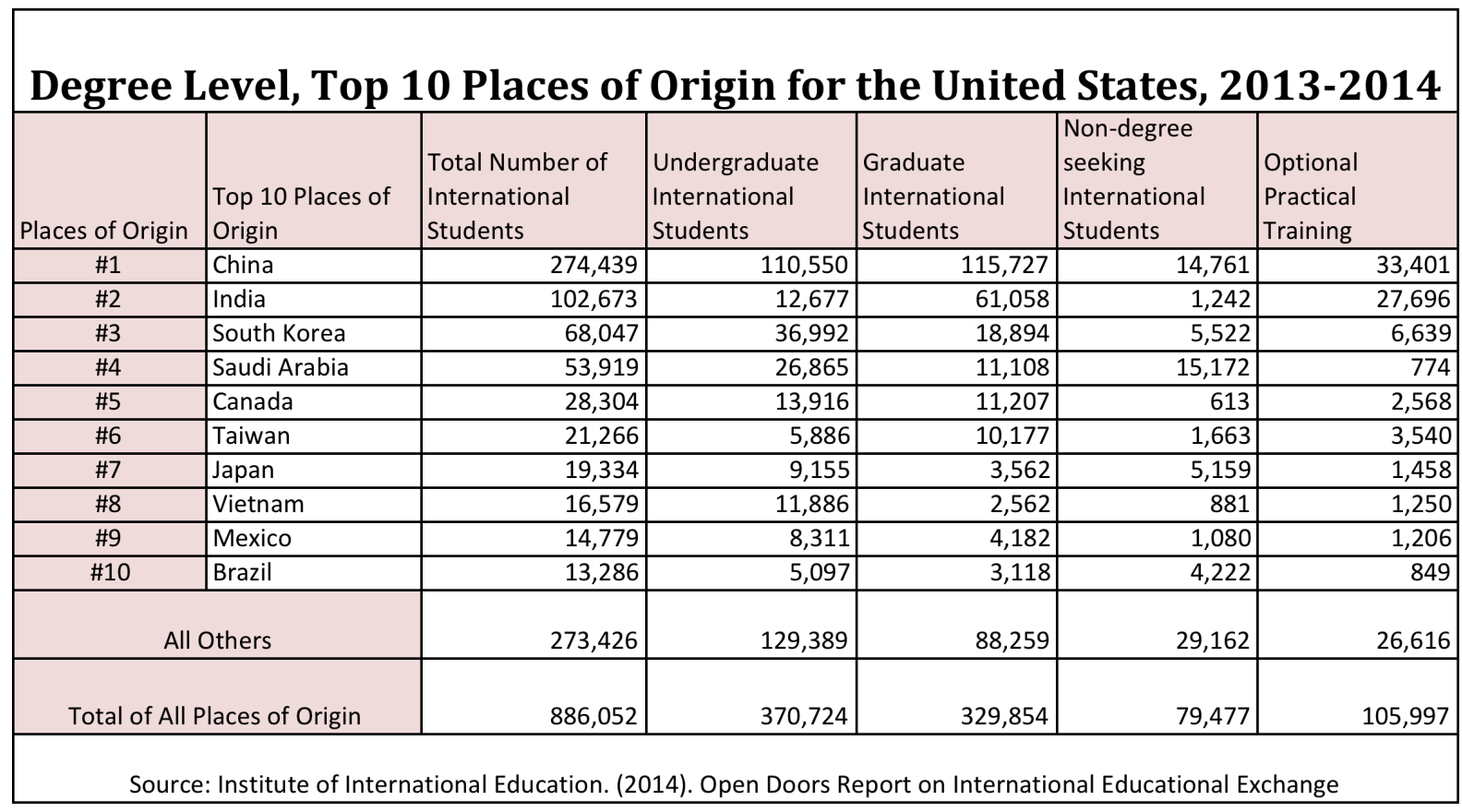

This research will introduce the study's theoretical framework, cultural hybridization theory, followed by a literature review describing the multiple discrepancies and extreme sociocultural differences between East Asian and Western academic cultures.

And the research questions are focused on examining East Asian international student academic subcultures from a cultural hybridization theory perspective:

- How can we utilize the cultural hybridization theory to analyze the international student academic subculture?

- What are the specific features of international students' academic subculture on U.S. campuses?

\section{Theoretical Framework}

\section{Cultural Hybridization Theory}

The term intercultural hybridizing process refers to transforming diverse cultural constructions in local cultural perceptions in the global context. (Bhabha, 1994). Cultural hybridization is a complex term with multiple definitions by scholars (Bhabha, 1994; Rowe \& Schelling, 1991; Tomlinson, 1991; Werbner, 1997).

Moreover, cultural hybridity in the post-colonial perspective can be viewed as a reaction to cultural hegemony (Bhadha, 1994). For example, a previous colony can either fully adopt the prior colonial cultural or act in opposition and retreat to a local culture or completely reject the prior colonial culture. And cultural hybridization is a latent variable, not readily visible under the hegemonic dominant culture. The cultural hybridization process, in this paper an academic subculture, is initiated through a population utilizing the dominant culture as a starting point for their own culture creation. In other words, a population reacts to the dominant culture and may incorporate part of it into a new culture. For example, China was involved in a cultural hybridization process during its semi-colonial period. At that time, Chinese scholars were gradually impacted by Western culture and attempted to eradicate aspects of traditional Chinese culture during World War II. Furthermore, this new subcultural creation works against the rise of neoliberalism and a global economy. Neoliberalism is defined as the association "with a lot of neo-liberal rhetoric about individual freedom, liberty, personal responsibility, privatization and the free market." (Harvey, 2009). With the emphasis on individualism and privatization, the global economy and culture hegemony may become more diffuse. The cultural hybridization process creates new cultures and can be viewed as a reaction to the fragmentation of global cultural identity. It is a creation of multicultural consciousness in which there is a diverse culture and ideology within a decentralized context. As can be seen from the above analysis, cultural hybridization is complex with controversial definitions. This research views cultural hybridization as a neutral term that conveys the essential process of hybridization without external bias. Cultural hybridization, in other words, is the creation of a rich hybrid cultural perspective from the incorporation of multiple cultures.

In terms of East Asian and the United States cultural hybridity, both China and America have promoted and implemented political strategies to create and expand intercultural ideologies, concepts, and ideas to facilitate soft cultural powers. In the worldwide higher education realm, China has a tendency to embrace American academic culture, which includes the learning assessment system, advising system, credit hours principles, effective teacher evaluation 
system in response to the worship of American academic democracy and freedom. On the other hand, America tries to understand Chinese traditional academic essences, such as Confucian' expectation (zun shi zhong dao) (Yu Han, A.D. 768-824). It is clear from these facts that both countries analyze and may incorporate educational culture elements of the other; this reproduction is essential in cultural hybridization. Specifically, from the cultural hybridization perspective, in higher education the Eastern soft cultural power has not threated the dominated status of American cultural ideology. Conversely, the mutual understanding of different attributes contributes to an innovative discourse in the globalization era. In short, the intercultural hybridization mutually benefits both Western and Eastern academics in global culture context. The next section, the literature review will illustrate the extreme educational differences in the East Asian educational Confucius system and the United States to provide further background on the academic cultures East Asian international students have when studying in the United States higher educational systems.

\subsection{Literature Review}

Broadly speaking, academic culture is fundamentally significant in the creation of a successful university and an individual in a global effective higher education system. A vibrant and diverse academic environment guarantees the highest probability of success in high levels of productivity and performance. (Altbach, 2012) Moreover, the academic environment is closely associated with development and reflections of academic culture. The term academic culture in higher education refers to academic attitude, beliefs and values held by academics in connection to different aspects of academics (Collins English Dictionary, 1994). These factors are found in higher education institutions. Additionally, academic culture includes regulations and principles in term of political, cultural, and economic elements. A set of academic attitudes, beliefs, and values integrate a specific group of academics (Maassen, 1996). Moreover, academic culture is consistently involved in academic learning, communications and actions on both instrumental and symbolic levels (Chaffee and Tierney 1988). Moreover, prior research claims that China and the United States have a maximum sociocultural difference (Yan and Berliner, 2011; Yan and Berliner, 2013). An introduction of Eastern and Western academic culture will be included in this section followed by an analysis of these cultures through a cultural hybridization perspective.

\subsection{East Asian Traditional Academic Culture}

In East Asia, higher educational principles and cultures are deeply rooted in traditional and contextual culture. The most significant influences for academic culture in East Asia are traditional Confucius concepts. It plays a fundamental role in continually cultivating traditional academic culture in East Asia. Moreover, East Asia developed its rich academic traditions in learning and teaching processes that contrast sharply to those in Western academic traditions. Specifically, Eastern academic traditions concentrate on absorbing knowledge of human society with its central focus on political and cultural unity controlled by the academic ruling classes. Moreover, the strict examinations systems to enter the scholarly ruling class and memorization of selected scholarly texts in order to enter the ruling class are key elements of ancient East Asia academic cultures. In the East Asian academic learning process, memorizing and summarizing ideas and concepts while being respectful of instructors and senior scholars is essential (Abelman \& Kang, 2014; Liao \& Wei, 2014; Tsai \& Wong, 2012; Yan \& Berliner, 2013). These characteristics are the fundamental competences required to be qualified scholarly student in an East Asian university. Moreover, the Confucius higher education learning process emphasizes on cultivating the abilities of connectedness and integration within a collective society in areas such as "Between theory and practice, fact and value, individual and community, institution and political-social-natural context' (Hayhoe, 2001, p.347; Tsai \& Wong, 2012; Yan \& Berliner, 2013). Friendships among peers are based on the trading of favors and having "a close relationship"; moreover, indirectness is valued (Yan \& Berliner, 2013). Thus, in East Asia, following and cultivating Confucianism and personal intellectual cultivation can still be considered as fundamental points for modern students. From my perspective, today, in East Asia, on the one hand, modern universities have their institutional established based on Western values and ideas of a university as a visible external variable; on the other hand, another traditional Confucius academic system by traditional academic culture as a central latent internal variable also influences the development of higher education traditions in East Asia.

\subsection{Western Traditional Academic Culture}

Western academic cultures also began developing centuries ago. Two specific elements that should be emphasized are academic freedom and responsibility. The university's origin in the West was rooted in Europe during the Middle Ages and the concept was developed by Germany. Since the $20^{\text {th }}$ century, faced with the spread of colonization and the emulation of scientific performance, America contributed to building academic principles and traditions across other Western countries. Since then, more and more countries began to experiment with similar universities in late $19^{\text {th }}$ century. (Cope, 2007). The value of the Western university is concentrated on autonomy and academic freedom in contrast to a strong sense of academic authority and hierarchy in East Asia. In the Western academic system, academic freedom is essential to a free society. "To impose any strait jacket upon the intellectual leaders in our colleges and universities would imperil the future of our Nation" (Sweezy V. New Hampshire, 1957, p. 250). America is deeply committed to safeguarding academic freedom as the unequivocal principle in its educational system. Academic freedom as a significant attribute provided a baseline for academic stakeholders- faculty, 
students and researchers in Western academic cultures. In America, academic freedom has diverse implications both as an essential principle of higher education system and in law (Cope, 2007). Specifically, "the principles of academic freedom as rights of faculty members in the areas of inquiry and research, classroom teaching, and life outside the institutional settings; academic freedom for students is defined as the freedom to learn." (James D. Jorgensen et al., 2008, p.5).

The academic principles of responsibility are another central element to Western academic cultures. "Max Weber advocated an ethic of responsibility as an alternative to ethic based on good personal intentions." (Charles H. Reynolds, 1990, p. 32) From the Weber perspective, powerful academics should engage in a kind of ethical reasoning that weighs and estimate the likely outcome concerning for the public policy decision making. Weber emphasized a responsible professional ethic in terms of awareness of tremendous new forms of power those politicians. It is appropriate for higher education institutions to explore an ethic of responsibility and academic principles that can lead the decision making both for individuals and higher education institutions. Conversely, in Eastern academic cultures, Confucianism concentrates on academic rules as guidelines to ethical behavior. In the Eastern academic professional ethic, Taoism suggested that relying on ethical principles is the only pathway to reach deep values that the individual avoid superficial and pious behaviors in terms of Eastern academic professional ethic. The hermeneutic of academic ethics is necessary both for Eastern and Western in higher education academic cultures. The ethic of responsibility is to guide decision making from critical perspective in higher education, we should agree on the ethical principles appropriate to our profession; make a decision procedure for utilizing those principles and understand moral judgment. (Charles H. Reynolds, 1990, p. 35). In contrast, academic ethics as a subjective discourse is critical in order to generate rationale for existence of academics in Western academic cultures.

Currently, the coexistence of Eastern and Western academic cultures, which are based on strikingly different academic cultural values and concepts, indirectly influences the current academic cultures in global educational system. Facing a different social, political and historical situation, how to create a new culture that combines Eastern and Western academic cultures still confuses international students, especially those from East Asia in the U.S. educational context. As mentioned previously, East Asian academic principles and cultures differ quite drastically from its Western counterparts. It is hardly surprising considering the tremendous academic cultural differences at the foundation of the two traditions. The awareness of academic cultural differences stimulates international students from East Asian to cultivate and generate new academic subcultures in their current Western campus environments.

In accordance with the factors and influences listed above, universities and institutions in U.S. should be concerned about the existing academic subcultures in U.S. classrooms and research them both quantitatively and qualitatively. Specifically, the notion of creating a mixture of Western and Eastern academic culture should be promoted for administrators and policymakers in current U.S. universities. It also urges us to reflect on the influence of "Western" anxieties on perceptions of the changing geopolitical architecture of higher education located within an East-West binary which imagines Asia to be the West's "other" (Bhabha 1994).

\subsection{Academic Subcultures from a Cultural Hybridization Perspective}

From a cultural hybridization perspective, the intercultural hybridizing process in global higher education academics transforms diverse academic cultural constructions to other academic cultural perceptions. The academic subculture is also considered as one significant form of generalized academic cultures. The incentives for host countries to promote international students have contributed to economic, academics and cultural strategies. For example, the U.S. has a prestigious tradition of welcoming international students, benefiting from its high level academic position. First, from the academic cultural perspective, international students have received cultural benefits from their host countries and, in return, they contributed to generate innovative academic richness by combination and adaptation of Western and Eastern academic cultures. Second, from an economics viewpoint, international students contribute financially through the payment of tuition fees, travel, leisure activities, and accommodation. (IIE, 2010) The latest report from IIE highlights that the increased international students within North America may be crucial to develop U.S. highly skilled labor force in response to the mainstream of knowledge-based economy. "It is of paramount importance to further develop the framework and structures of international student mobility in the long term." (Carlos Rodríguez González, 2011) Thus, academic performance and development of international students potentially influences the trends of knowledge -based economy in host country.

From the cultural hybridization perspective, the hybridization process refers to the loss of original attributes, increases of hegemonic elements and generation of new cultural features, which are considered as key features of the concept of cultural hybridization. More specifically, in the field of higher education, international students are at the position where they integrate separate Eastern and Western academic cultural attributes into a set of universal academic characteristics. For example, Chinese students are currently the largest number of international students in the U.S. (IIE, 2010) In the higher education field, the rapid growth of Chinese students has a significant impact on generating innovative academic subcultures. Prospective students are encouraged to study overseas and the proliferation of the expansion of local provision by foreign universities provide Chinese students an effective platform to access foreign 
degrees, do nations in order to cultivate academic hegemonic attributes through new forms of academic subculture.

Specifically, cross-border education is considered as a visible model to facilitate academic subculture in market-driven global higher education system. A large number of international students, especially students from China, and India, are attracted by developed countries, which includes United Stated, United Kingdom, France, Germany, and Australia (IIE, 2010). The most visible components of cross-border education involve in students' mobility within and without nation in the global environment. In the context of higher education academic culture, East Asia and the West provide different academic cultures historically and contextually. The distinct discrepancies, which include the learning process, student -faculty relationship, campus environment, and campus environment have enlarged the academic cultural gaps between Western and Eastern cultures. For instance, in the U.S. higher educational academic cultural tradition, the advocacy of Western academic traditions, concerning on critical thinking, rational reflection, academic freedom, independent thinking and participant learning, active and interactive student-faculty relationships, diverse and plural campus environment, collaborative learning processes, and providing internal and external structural impulses to promote acceleration of the higher education development. However, in the Chinese higher education cultural convention, the traditional academic attributes, focusing on academic authority, academic hierarchy in learning process, regular and hierarchical student-faculty relationship, oriented and collective campus environment, have impeded the progress of innovative teaching and learning. (See. Table 3) International students profoundly incentives to combine and mix Western and Eastern academic cultures to generate academic subcultures among peers in the cultural hybridization processes in current global context; in other words, they are the catalyst that tend to generate new forms of academic subcultures in the worldwide cultural hybridization process.

\section{Methodology}

This research utilizes semi-structured interviews for international students from East Asia countries, including China, South Korea, and Japan studying in the U.S. from the last five years (2010-2015). Before conducting interviews, relevant literature reviews related to academic cultures, international student mobility, and cultural hybridization theories were reviewed by the interviewer. Based on the in-depth literature reviews mentioned previously, several semi-structured questions are utilized to analyze specific features of academic subculture in international student groups from East Asia. Interview questions contained five aspects: academic convention, student-faculty relationship, campus environment, learning process, and peer's learning relationships.

\subsection{Participants}

This research had fifteen participants (eight females, seven males) with the age ranging from 20 to $27 .(\mathrm{M}=24)$. Specifically, seven students were enrolled in graduate schools and eight students were enrolled in undergraduate school in U.S. universities, majoring in Science (5), Social Science (7), and Engineering (3). The interviewees contained ten Students who came from Mainland China, three students from South Korea and two students from Japan. Specifically, most interviewees grew up in coastal developed parts in their nations. Almost all the international student participants stayed for an average of 3 years in the United States. Most of them also participated in diverse international short-term exchange programs before they arrived to the U.S. (See Table 3)

Table 3. Interviewee' Basic Information

\begin{tabular}{|c|c|c|c|c|c|}
\hline Interviewee & Gender & Age & Degree & Discipline & Nationality \\
\hline AC1 & M & 25 & Graduate & Science & China \\
\hline AC2 & M & 22 & Undergraduate & Social Science & China \\
\hline AC3 & M & 26 & Graduate & Social Science & Japan \\
\hline AC4 & F & 24 & Graduate & Science & China \\
\hline AC5 & M & 22 & Undergraduate & Social Science & China \\
\hline AC6 & F & 21 & Undergraduate & Science & South Korea \\
\hline AC7 & F & 21 & Undergraduate & Engineering & China \\
\hline AC8 & F & 20 & Undergraduate & Engineering & Japan \\
\hline AC9 & M & 24 & Graduate & Science & China \\
\hline AC10 & M & 26 & Graduate & Engineering & South Korea \\
\hline AC11 & F 12 & 27 & Graduate & Science & China \\
\hline AC13 & M & 22 & Undergraduate & Social Science & China \\
\hline AC14 & F & 21 & Undergraduate & Social Science & China \\
\hline AC15 & F & 21 & Undergraduate & Social Science & . \\
\hline
\end{tabular}




\subsection{Data Collection}

Data for this research was collected using semi-structural interviews. The interviewers began by facilitating an initial planning meeting where these fifteen participants discussed the whole goals and ideas of this research, including ethics and responsibilities related to engaging in this research and recording devices. Moreover, the interview processes consisted of two main rounds. The first round focused on demographic questions about participants' credentials, which included gender, age, marital, education status, international experience. This round was loosely structured and intended to enrich the researcher's scope and insight into international students from China, Japan, and South Korea international experiences and academic cultural adaption capacity. The interview locations were at Peking University and Beijing Normal University in Beijing, China during the 2015 summer break. In the second round, we conducted one-to-one interviews with these fifteen participants. The author asked open-ended questions:

- "How do you feel about the international education in U.S.? "Can you give me an example about this?"

- "What challenges you have experienced while interacting with your advisor, peers, and staff in daily academic life?

- "What forms of academic training you have experienced and what differences can you compare academic culture between China and U.S.?

- "What is it like to be an international students working with peers, faculty in campus environment?"

- "How do you deal with your U.S. academic assignment? Do you have strategies or examples for your experience?

Moreover, these participants initially received this research introduction through email before the formal interview processes in order to allow participants to completely understand this research context before beginning the interview process. In addition, before conducting interviews, all fifteen interviewees signed confirmation forms of acceptance of interview based on IRB instructions and principles; two copies were made for each interviewee. Before conducting the interviews, each interviewee was required to carefully read and sign the research confirmation forms. A summary of categories under different domains and specific examples in the processes of interviews is shown in the following parts, using pseudonyms to protect interviewees' social identity in response to the requirements of IRB instructions (H.H.S, 2015).

\subsection{Data Analysis}

In the data analysis, the research was analyzed through the Consensual Qualitative Research Method (CQR), which can improve research trustworthiness, to analysis these interviews. (Hill et. al. 2005) In this method, in the first round, the researchers examine these interview transcripts to develop domains for group topics. Then, these groups' topics were discussed until the researchers reached the same consensus. In order to reach consensus, researchers discussed their ideas and concepts with peers, scholars and faculty members. In the third round, the significant ideas and concepts were articulated in cross-case analysis processes. In response to guarantee the trustworthiness of interviews, collecting an adequate description of interviewees' response, double blind checking of transcripts are implemented in this research process. If it is possible in further research, external auditors can provide insights to ensure the comprehensive consideration in the analysis processes.

\subsection{Limitations}

Several limitations in this research need to be discussed. First, the limitation of sample sizes might result in less accurate and adequate information from the interviews. However, the diverse samples can help promote the validity of this research. Second, this is an initial research study in the field of utilizing the cultural hybridization theory to analyze the international student mobility in the higher educational academic culture themes. Third, from the theoretical framework perspective, the critiques and limitations of the cultural hybridization served as another limitation in terms of the clear articulation of the international student mobility and education academic cultures. Specifically, the conceptual ambiguity of cultural hybridization discussed in the theoretical framework section served as a distinct critique in term of divergence on the definition and implication of cultural hybridization.

\section{Findings}

\subsection{The Learning Process \& Peers' Learning}

In the learning process, international students from East Asia generate their own academic subgroups to be participants and collaborative learners in contrast to critical and independent thinking of Western learning traditions and absorbing/memorizing texts of Eastern academic traditions. They have the tendency to be collaborative learners in specific subgroups among peers. In a social-cultural context, the term subcultural group is defined as an ethnic regional, economic, or social group exhibiting characteristic patterns of behavior sufficient to distinguish it from others within an embracing culture of society. (Merriam-Webster, 2015) In the global educational context, academic subcultural groups among international students from East Asia refer to subgroup members share important associations within internal groups under latent consciousness. In addition, in peers' learning, international students would like to choose effective informational peer learning to complete their own assignments and projects comparing with collaborative peer touring in Western and individual learning in Eastern. 
Some students shared the following information:

- One student said that, "it was really difficult for me to study in these courses. I did not have ideas to fulfill homework, assignments, and group projects when I was a freshman in ECE program. It was terrible to me and I realized that U.S. academic context is pretty different from Korean academic context. However, the goals in U.S. academic context, we should have an ability to cope with multi tasks, such as readings, writings, group study, project presentation, final paper, and final presentation. And after only one month, I have engaged in our peer groups. In our group, we are all majored in ECE and faced with same barriers. The most important thing is we are Korean and always share our learning experience, assignments, and projects. Like my family, we gradually generate our own successful learning practice. " (AC7)

- One student said that, "Our group among Chinese peers gave me invaluable learning experience and skills to my research and study. I really enjoyed talking with my peers among our small learning groups. They broaden my scope and encouraged me to critique knowledge rationally. I found that it is an effective way to learn. We often discuss together in our small peer groups." (AC2)

"For my assignment and project, we also share useful examples, answers, informative tools to complete our own assignment and project individually. Just like sharing effective and useful material and methods among our peers and then finish them by our self. We would not like to get together to deal with the same task like Americans. Because I am interested in valuable materials among peers." (AC9)

\subsection{Classroom Cultures}

There are many differences between the U.S. and East Asia in classroom cultures. Actually, the key discrepancies between U.S. and East Asia in terms of classroom cultures are the two distinguish between active student-centered approach and hierarchical and respectful teacher-centered approach. Specifically, the classroom cultures are rooted in historical pedagogical and culture values' development. For example, in the Chinese classroom culture context, the learner's responsibility is focused on listening to lectures, taking notes, reading assigned textbooks or articles, demonstrating memorization in exam and class notes; Generally speaking, the international students' classroom cultures highlight the importance and accessibility of solving problems based on problem-oriented perspective. Most of the international students gradually generated their own specific inactive problem-oriented behaviors within classrooms.

In the interview process, one student said that:

- "I remembered that, when I was the first year graduate student in EDUC. I felt that it is so terrible for me to communicate and talk in classroom. I have no idea to express my ideas and felt extremely nervous to present my own ideas in the group discussion section. It is my first time to be a participant in groups. In China, we just need to listen, remember and summarized the contents of lectures. Generally speaking, most of international students always keep in silence and inactive. We have adapted in this sort of classroom performance. Actually, we all focused on what is and how is and we less focused on why it is. We have certain learning target and goals to participate in classroom." (AC14)

- "On campus, we just play with our peers. We often go shopping together. We seldom hang out individually. We usually organize small peers' groups on campus. My best friends are also in our small group. We almost have no American friends. I mean, we are just classmate with other classmates on campus." (AC2)

\subsection{Differences in Academic Principles}

Each culture has its specific cultural standards, rules, norms regarding historical and contextual conducts and behaviors. Generally, the distinct discrepancy between Western and Eastern refers to the definitions and explanations of values. International education in the United States has provided international students from East Asia more opportunities to rethink and reflect Eastern traditional academic beliefs. Additionally, the obvious distinctions between academic principles are the worship of academic freedom and academic authority. Engaging in two different kinds of academic values, international students cultivate integral academic principles of internal academic authority and external academic freedom. For example, as shown in the transcript below:

- $\quad$ "In my opinion, it is difficult to discard traditional academic beliefs of academic authority inherently. And we are also exposure to U.S. academic values of academic freedom. So maybe, I found that the combination of Eastern and Western academic norms and values is regard as one specific features among our foreign students." (AC10)

- "I believe in both academic values. You know, we live in the edge of these two academic beliefs. The overlapping influences are rooted in my daily academic activities. Breaking up the integrate effect is impossible for us." (AC5)

\subsection{Faculty-Student Relationship}

International students from East Asia always remain inactive in interactions with professors. They seldom actively connect with professors by email or conversations in terms of academic affairs. Moreover, from the intercultural hybridizing perspective, the international groups are dually influenced by traditional Eastern hierarchical faculty and student relationships and Western proactive and more friendly relationships. The internal hierarchical faculty and 
student relationships greatly affect the international students' performances.

- "I have never actively send email to my advisor in terms of academic questions. If I am faced with a hot potato, I will talk with my peers and ask for help usually. It is a timesaving pattern for me to cope with academics. I found other international students did as what I did usually." (AC7)

- "To me, our professors are professional and nice. But we just talk in classroom and I never send email or messages to them to ask for some academic problems or academic plan anything else. I knew other American students are active to connect with professors on / off campus. They share a friendly relationship among them." (AC12)

In conclusion, cultural hybridization resulted in the international student participants encountering a new culture, reflecting on their culture of origin and the new hegemonic culture, and creating an academic subculture within a US higher education institution. Specifically, under dual academic cultures, international students from East Asia encounter extreme challenges and opportunities in adapting, recognizing and generating flexible academic cultural behaviors. However, the trend of international student mobility provides an effective and open pathway for students from different cultural identities to integrate and connect to generate a new fundamental and global universal academic culture.

Table 4. Comparison among Western academic culture, Eastern academic culture and Sub-academic culture

\begin{tabular}{|c|c|c|c|}
\hline & $\begin{array}{c}\text { Western } \\
\text { academic } \\
\text { culture }\end{array}$ & $\begin{array}{c}\text { Eastern } \\
\text { academic } \\
\text { culture }\end{array}$ & $\begin{array}{l}\text { Academic } \\
\text { Subculture }\end{array}$ \\
\hline \multirow[t]{2}{*}{$\begin{array}{l}\text { Learning } \\
\text { Process }\end{array}$} & $\begin{array}{l}\text { Critical } \\
\text { Thinking }\end{array}$ & $\begin{array}{c}\text { Absorb } \\
\text { Knowledge }\end{array}$ & $\begin{array}{l}\text { Participant } \\
\text { Learning in } \\
\text { subgroups }\end{array}$ \\
\hline & $\begin{array}{l}\text { Independent } \\
\text { Thinking }\end{array}$ & $\begin{array}{l}\text { Memorize } \\
\text { Texts }\end{array}$ & $\begin{array}{l}\text { Collaborative } \\
\text { Learning in } \\
\text { subgroups }\end{array}$ \\
\hline \multirow{2}{*}{$\begin{array}{l}\text { Academic } \\
\text { Principles }\end{array}$} & \multirow{2}{*}{$\begin{array}{l}\text { Academic } \\
\text { Freedom }\end{array}$} & \multirow{2}{*}{$\begin{array}{l}\text { Academic } \\
\text { Authority }\end{array}$} & $\begin{array}{c}\text { Academic } \\
\text { Freedom } \\
\text { (externalization) }\end{array}$ \\
\hline & & & $\begin{array}{c}\text { Academic } \\
\text { authority } \\
\text { (internalization) }\end{array}$ \\
\hline \multirow[t]{3}{*}{$\begin{array}{c}\text { Student-Faculty } \\
\text { relationship }\end{array}$} & Active & Hierarchy & $\begin{array}{c}\text { Inactive\& } \\
\text { distance }\end{array}$ \\
\hline & Interactive & Regulation & Respectful \\
\hline & $\begin{array}{l}\text { Learning } \\
\text {-centered }\end{array}$ & $\begin{array}{l}\text { Teaching- } \\
\text { centered }\end{array}$ & $\begin{array}{l}\text { Problem } \\
\text {-centered }\end{array}$ \\
\hline \multirow[t]{2}{*}{ Campus Climate } & Diverse & Oriented & $\begin{array}{l}\text { Subgroup } \\
\text {-oriented }\end{array}$ \\
\hline & Plural & Collective & $\begin{array}{l}\text { Cultural } \\
\text { Identity } \\
\text {-oriented }\end{array}$ \\
\hline $\begin{array}{l}\text { Classroom } \\
\text { Climate }\end{array}$ & $\begin{array}{c}\text { Active } \\
\text { Student } \\
\text {-centered }\end{array}$ & $\begin{array}{l}\text { Mannered } \\
\text { Teacher } \\
\text {-centered }\end{array}$ & $\begin{array}{l}\text { Inactive } \\
\text { problem } \\
\text {-oriented }\end{array}$ \\
\hline Peers' Learning & Collaborative & Individual & $\begin{array}{c}\text { Effective } \\
\text { informational }\end{array}$ \\
\hline
\end{tabular}

\section{Discussion}

\subsection{Peer Academic Subgroup}

Based on the data analysis of this research, the peer cultural identity within subgroups is essential for international students to engage in U.S. academics. It is the reason why it is inevitable to establish a peer subculture among international students in current U.S. academics. The peer academic subculture involves diverse academic relationships in multiple dimensions in current U.S. campus. Specifically, "Peer groups are defined by members' shared experiences, including norms, values, and behaviors" (Ryan, 2000). The nature of a peer group is mutually determined culture by all participants (Ryan, 2000). "In peer groups, peers shared beliefs about the group's expectations for effort and achievement that significantly differentiated peer groups." (Hamm et al., 2011) Peer subcultures are constructed by students through the processes of interaction and connection within cultural expectations in higher education institutions (Liao \& Wei, 2014) Coordinating classroom social dynamic through classroom management is a big challenge for instructors in current US campus life. It is crucial to faculty and administrators at United States to promote their students' academic competence and encourage all students' academic engagement all, including their international student populations.

\subsection{Peer Academic Subculture}

The specific characteristics of the academic subculture fundamentally impact the academic activities of international students. Broadly speaking, international students identify with their academic subculture through cultural and regional dimensions. The importance of personally experiencing a sense of community at higher education institutions is equally significant both in and out of classrooms. International students' academic subculture provides subjective motivation to engage them into academic life in U.S. campus. Moreover, classroom academic involvement is an important factor of international students' academic subculture and directly impacts academic learning performance and outcomes. A sense of academic community is central to international students' learning engagement and performance. Academic subculture among international students from East Asia is in the continual process of building institutional academic identification. The academic subculture reflects specific snapshots of the international undergraduate and graduate students in U.S. campus currently. Moreover, the academic subculture is directly associated and interplays with the academic substructure of population in U.S. universities. International students from East Asia are exposed to Western academic cultures, professions and principles and then generate their new and innovative academic subculture to be competitive with peers consistently. More specifically, in the learning process, international students have tendency to be participant and 
collaborative learners within peer subgroups; In terms of academic principles, they are beginning to hold a dual academic belief: both academic freedom as an external factor and academic authority as an internal factor. Thus in faculty- student relationships, they remain inactive and display polite attitude toward faculty- student relationships; in the classroom atmosphere, international students are characterized as an inactive problem-oriented groups. (See Table 4)

Moreover, academic subcultures and subgroups among international students are becoming more and more popular in current U.S. international higher education systems. Generally speaking, it is fundamentally significant for international students in academic subcultural groups to develop trusting relationships, build learning competence, create opportunities for learning creating, engaging learning experiences. However, it is still difficult to embrace international students to engage in U.S. classroom climate in terms of different academic values, cultures and principles. Because developing trusting relationship between American students and international students is connecting with two different academic cultures. Thus, the frustration of adapting Western academic culture pushes international students to seek new academic subculture in U.S. campus. From the cultural hybridization perspective, the emergence of international academic subcultures through the increasing numbers of international students positively incentives cultural integration, reproduction and innovation in international higher education. In the paradigm of cultural hybridization, it is inevitable for U.S higher education institutions to promote active and positive interaction, communication, and exchanges strategies in higher education academic activities in terms of international education is generating universal approaches to the innovative understanding of academic democracy and international trend principles and international students is creating new academic subcultures.

\subsection{Implications}

In the global context, the trend of international education attracts and provides adequate opportunities for students from different educational, cultural, political, regional backgrounds to connect, interact, recognize, communicate, integrate and regenerate innovate and profound academic cultures in the sphere of higher education systems. Meanwhile, the processes of recognition and reflection generate powerful and explicit discourses to reconstruct academic cultural identities in the processes of academic cultural production and consumption in the confliction of globalization and localization. The academic subculture can play a role of creating new cultures that can spread mitigate the fragmentation of global cultural identity and skill sets. This is a significant implication of why advocacy of international education from a cultural hybridization perspective should be pursued in the global context.

Although international students currently are characterized as having a set of diverse characteristics, it is imperative for subcultural groups of undergraduate and graduate students to be collaboration with peers, faculty, and staff in pursuit of academic performance in American higher education institutions. In accordance with the trends of neo-liberalism and culture capitalism, it is essential to integrate academic subculture among international students from East Asia, strengthen international students' academic and cultural identity and make best use of academic subcultures to motivate academic performance and learning outcomes. Moreover, higher education institutions have the ultimate responsibility to develop programs and service that strengthen students' identity from different cultural background to effectively engage in academic conversations on emerging research ideas. Faced with the emerging academic subculture among international students from East Asia, faculty members should focus on effectively and in a timely manner supervising, mentoring, teaching and interacting with international students from East Asia countries. Additionally, it is conductive to provide valuable professional opportunities to academic subculture groups to enrich learning and research ideas. "Policies and resources can be enacted and resources targeted in an effort to channel student behavior toward activities that will enhance learning and personal development." (Kuh et al., 2000, p. 242). In order to investigate the relationship between the international student mobility and the higher education academic cultures, it is fundamentally significant to design academic culture questionnaires to measure and assess students' international academic capacity across-nations and across cultures. Additionally, building sufficient and sustainable academic success projects or mechanism for international students can provide effective approaches to encourage motivation and inspiration for international students essentially.

\section{REFERENCES}

[1] Abelmann, N., \& Kang, J. (2014). A fraught exchange? US media on Chinese international undergraduates and the American university. Journal of Studies in International Education, 18(4), 382-397. DOI:

$10.1177 / 1028315313479852$

[2] Altbach, P. G. (2004a). The question of corruption in academe. International Higher Education, 34, 8-10.

[3] Altbach, P. G., \& Umakoshi, T. (2004b). Asian universities: Historical perspectives and contemporary challenges. Baltimore, MD: The Johns Hopkins University Press.

[4] Altbach, P. G. (2010). The Asian higher education century? International Higher Education, 59, 3-5. DOI: 10.1007/978-84-6209-338-6_31

[5] Altbach, P. G. (2012). The prospects for the BRICs: The new academic superpowers?. Economic and Political Weekly, 47(43), 127-137. DOI: 10.1057/9780230369795_1

[6] Kehm, B. M. (2005). The Contribution of International 
Student Mobility to Human Development and Global Understanding. US-China Education Review, 2(1), 18-24.

[7] Bhabha, H. K. (1994). The location of culture. London, U.K.: Routledge.

[8] Cope, K. L. (2007). Defending the ivory tower: A twenty first century approach to the Pickering-Connick doctrine and public higher education faculty after Garcetti. Journal of College and University Law, 33(2), 313-360.

[9] Reynolds, C. H., \& Smith, D. C. (1990). Academic principles of responsibility. Ethics and Higher Education. New York: Macmillan, American Council on Education.

[10] Dictionary. C. E. (1994). Collins English Dictionary. Glasgow, U.K.: HarperCollins.

[11] González, C. R., Mesanza, R. B., \& Mariel, P. (2011). The determinants of international student mobility flows: an empirical study on the Erasmus programme. Higher Education, 62(4), 413-430. DOI: $10.1007 / \mathrm{s} 10734-010-9396-5$

[12] Chinese Ministry of Education Annual Work Report 2014. (2015, December). Retrieved from http://www.iie.org/Who-We-Are/News-and-Events/Press-Ce nter/Press-Releases/2014/2014-11-17-Open-Doors-Data

[13] Harvey, D. (2009). The crisis and the consolidation of class power: Is this really the end of neoliberalism? Counterpunch 13-15 March.

[14] Habermas, J. (1989). The structural transformation of the public sphere (T. Burger, Trans.). Cambridge, MA: Massachusetts Institute of Technology Press (Original work published 1962).

[15] Hamm, J. V., Schmid, L., Farmer, T. W., \& Locke, B. (2011). Injunctive and descriptive peer group norms and the academic adjustment of rural early adolescents. The Journal of Early Adolescence, 31(1), 41-73. DOI:

$10.1177 / 0272431610384486$

[16] Hayhoe, R. (2001). Lessons from the Chinese academy. Knowledge across cultures: A contribution to the dialogue among civilizations, 323-347.

[17] Hill, C. B., Knox, S., Thompson, B. J., Williams, E., Hess, S. A., \& Lad any, N. (2005). Consensual Qualitative Research: An update. Journal of Counseling Psychology, 52, 196-205. DOI: $10.1037 / 0022-0167.52 .2 .196$

[18] Bammer, A. (1994). Displacements: Cultural identities in question (Vol. 15). Bloomington, IN: Indiana University Press.

[19] Bhabha, H. K. (1996). Culture's In-Between" in Questions of Cultural Identity. London, UK, Sage Publications.

[20] IIE Institute of International Education. Retrieved from http://www.iie.org/.

[21] Liao, K.Y.H. and Wei M. (2014) Academic stress and positive affect: Asian value and self-worth contingency as moderators among Chinese international students. Cultural Diversity and Ethnic Minority Psychology 20(1): 107-115. DOI: $10.1037 / \mathrm{a} 0034071$

[22] Maassen, P. A. (1996). The concept of culture and higher education. Tertiary Education \& Management, 2(2), 153-159.
[23] OECD. Retrieved from http://www.oecd.org/

[24] Merriam Webster. Retrieved from http://www.merriam-webster.com/dictionary/subculture

[25] U.S. Department of Health \& Human Services. Retrieved from http://www.hhs.gov/ohrp/assurances/irb/

[26] UNESCO Institute for Statistics (UIS): UNESCO Statistical Yearbook and the UIS publication entitled Global Education Digest, UNESCO. Retrieved from http://en.unesco.org/.

[27] Yang, R. (2015). Reassessing China's higher education development: a focus on academic culture. Asia Pacific Education Review, 16(4), 527-535. DOI: $10.1007 / \mathrm{s} 12564-015-9397-2$

[28] Rowe, W., \& Schelling, V. (1991). Memory and modernity: Popular culture in Latin America. London, UK: Verso Books.

[29] Ryan, A. M. (2000). Peer groups as a context for the socialization of adolescents' motivation, engagement, and achievement in school. Educational Psychologist, 35(2), 101-111. DOI:10.1207/S15326985EP3502 4

[30] John, Tomlinson (1991). Cultural Imperialism: A Critical Introduction. Baltimore, MD: The Johns Hopkins University Press.

[31] Pieterse, J. N. (1993). Globalization as hybridization. ISS Working Paper Series/General Series, 152, 1-18.

[32] Jorgensen, J. D., \& Helms, L. B. (2008). Academic freedom, the First Amendment and competing stakeholders: The dynamics of a changing balance. The Review of Higher Education, 32(1), 1-24.

[33] Song, Y. (2009). Cultural hybridization: Rethinking globalization in China and the US.

[34] Kraidy, M. M. (2002). Hybridity in cultural globalization. Communication Theory, 12(3), 316-339. DOI: 10.1111/j.1468-2885.2002.tb00272.x

[35] Kondakci, Y. (2011). Student mobility reviewed: attraction and satisfaction of international students in Turkey. Higher Education, 62(5), 573-592. DOI: 10.1007/s10734-0119406-2

[36] Yuan, B. T. (2011). Internationalization at home: the path to internationalization in Chinese research universities. Chinese Education \& Society, 44(5), 84-96. DOI: 10.2753/CED1061-1932440507

[37] Belyavina, R., Li, J., \& Bhandari, R. (2013). New frontiers: US students pursuing degrees abroad. A two-year analysis of key destinations and fields of study. New York, NY: Institute for International Education.

[38] Snyder, T. D., \& Dillow, S. A. (2015). Digest of Education Statistics 2013. NCES 2015-011. National Center for Education Statistics.

[39] Tsai, P. C., \& Wong, Y. J. (2012). Chinese and Taiwanese International College students' participation in social organizations: implications for college counseling professionals. Journal of College Counseling, 15(2), 144-156.

[40] Yan, K., \& Berliner, D. C. (2011). Chinese international students in the United States: Demographic trends, motivations, acculturation features and adjustment challenges. Asia Pacific Education Review, 12(2), 173-184. DOI:10.1007/s12564-010- 9117-x. 
2228 A Cultural Hybridization Perspective: Emerging Academic Subculture Among International Students from East Asia in U.S.

[41] Yan, K., \& Berliner, D. C. (2013). Chinese international students' personal and sociocultural stressors in the United States. Journal of college student development, 54(1), 62-84. DOI:10.1353/csd.2013.0010.
[42] Kuh, G. D., Hu, S., \& Vesper, N. (2000). "They Shall Be Known by What They Do": An Activities-based Typology of College Students. Journal of College Student Development, 41(2), 228-44. 